\title{
Renewing a partnership to further research and improve oral health
}

\begin{abstract}
Angela Della Gatta(a) José Eduardo Pelizon Pelino(a) Sigmar de Mello Rode ${ }^{(b)}$
\end{abstract}

(a) Johnson \& Johnson do Brasil - Oral Care Division

(b) Scientific Editor
$\mathbf{T}$ he mission of the Sociedade Brasileira de Pesquisa Odontológica (SBPqO), Brazilian Division of the International Association for Dental Research (IADR), is to promote, in the broadest sense possible, the development and visibility of research efforts in all areas of science, especially those contributing directly to the development of oral health. The Society's official venue of scientific dissemination is the Brazilian Oral Research journal (BOR).

One of the goals set by the $\mathrm{SBPqO}$ to accomplish this mission has been to collaborate with other dental scientific organizations. The present special issue marks the renewal of our partnership with the Brazilian Association for Oral Health Promotion (Associação Brasileira de Odontologia de Promoção de Saúde - ABOPREV) to showcase the studies presented and the symposium discussions held at the Association's $15^{\text {th }}$ International Congress in Brasilia, DF, in May 2010. Similarly to our first joint-venture publication, all papers were submitted to the scrutiny of BOR's reviewers for analysis and content approval.

Some of the papers published in the first BOR/ABOPREV special issue, in 2009, have been among the Journal's most searched and read articles for providing state-of-the-art compilations on the most important oral health issues today. This is why the papers in our special issues are somewhat different from the original research articles usually published in the BOR, in that they are more extensive and are predominantly literature review efforts.

Another partnership reflected in the pages of this special issue is one between the SBPqO and the SCC, a group formed by leading figures of the Brazilian teaching community, with the support of Johnson \& Johnson. This group is conducting a project that involves evaluating the teaching of Supragingival Dental Biofilm Chemical Control (SCC), through workshops to be held as part of dental courses in many colleges in Brazil. With this in mind, we decided to publish an article with the results of the first assessment conducted by the SCC, as part of this issue.

As an unprecedented gesture, this interesting issue will be distributed to all participants of the $27^{\text {th }}$ Annual Meeting of the SBPqO, to be held in Águas de Lindóia, SP, in early September of this year. The BOR subscribers and all members of the ABOPREV will also receive a copy.

We hope that this important effort will further our mission of promoting, disseminating and stimulating dental research in our country, and, as a result, contribute to improving the oral health condition of its inhabitants. 